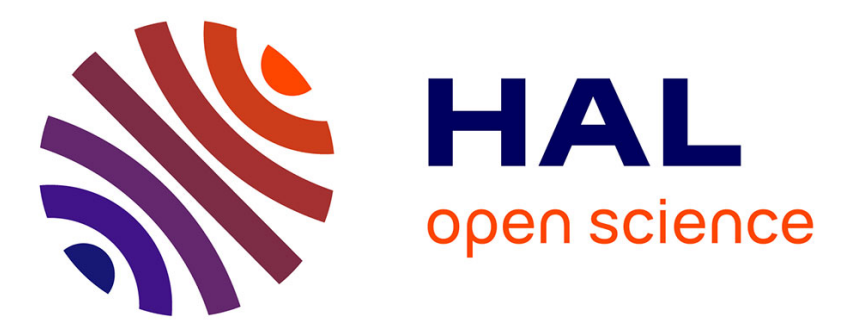

\title{
Crickets of the subfamily Eneopterinae (Orthoptera: Grylloidea) from Sandakan, Sabah: one new species and calling songs of a sympatric species
}

\author{
Ming Kai Tan, Razy Japir, Arthur Y.C. Chung, Tony Robillard
}

\section{- To cite this version:}

Ming Kai Tan, Razy Japir, Arthur Y.C. Chung, Tony Robillard. Crickets of the subfamily Eneopterinae (Orthoptera: Grylloidea) from Sandakan, Sabah: one new species and calling songs of a sympatric species. Zootaxa, 2019, 4619 (2), pp.347-363. 10.11646/zootaxa.4619.2.9 . hal-02433079

\author{
HAL Id: hal-02433079 \\ https://hal.science/hal-02433079
}

Submitted on 8 Jan 2020

HAL is a multi-disciplinary open access archive for the deposit and dissemination of scientific research documents, whether they are published or not. The documents may come from teaching and research institutions in France or abroad, or from public or private research centers.
L'archive ouverte pluridisciplinaire HAL, est destinée au dépôt et à la diffusion de documents scientifiques de niveau recherche, publiés ou non, émanant des établissements d'enseignement et de recherche français ou étrangers, des laboratoires publics ou privés. 
Crickets of the subfamily Eneopterinae (Orthoptera: Grylloidea) from Sandakan, Sabah: one new species and calling songs of a sympatric species

\author{
Running title: Eneopterinae from Sandakan \\ MING KAI TAN ${ }^{1 *}$, RAZY JAPIR ${ }^{2}$, ARTHUR Y.C. CHUNG ${ }^{2}$, TONY ROBILLARD ${ }^{3 *}$ \\ ${ }^{1}$ Department of Biological Sciences, National University of Singapore, 14 Science Drive 4, Singapore \\ 117543, Republic of Singapore. Email: orthoptera.mingkai@gmail.com \\ ${ }^{2}$ Forest Research Centre (Sepilok), Sabah Forestry Department, PO Box 1407, 90715 Sandakan, \\ Sabah, Malaysia.Email: razy.japir@sabah.gov.my (RJ); arthur.chung@sabah.gov.my (AYCC) \\ ${ }^{3}$ Institut de Systématique, Evolution et Biodiversité (ISYEB), Muséum national d'Histoire naturelle, \\ CNRS, SU, EPHE, UA, 57 rue Cuvier, CP 50, 75231 Paris Cedex 05, France. E-mail: \\ tony.robillard@mnhn.fr \\ * Corresponding authors
}

\begin{abstract}
Orthoptera from Sandakan, Sabah are relatively understudied compared to some other parts of Borneo, and lack of information of species there can impede our understanding of the origins and biodiversity of orthopterans in Borneo and, in general, Southeast Asia. Based on a recent orthopteran survey in Sandakan, one new species of Lebinthus Stål is described from Sandakan, Sabah, Borneo: Lebinthus sandakan sp. nov. The male calling song of this new species is also presented. The calling song of Cardiodactylus borneoe Robillard \& Gorochov, 2014 is also described for the first time.
\end{abstract}

Key words: bioacoustics, Borneo, new species, Southeast Asia, taxonomy

\title{
Introduction
}

The crickets of the tribe Lebinthini (subfamily Eneopterinae) can be found in Southeast Asia and the Western Pacific, and include speciose genera Cardiodactylus Saussure, 1878 (81 species) and Lebinthus Stål, 1877 (16 species). Works on the taxonomy (e.g., Robillard \& Tan, 2012; Tan \& Robillard, 2014; Robillard et al., 2014, 2016; Vicente et al., 2015) and systematics (e.g., Robillard \& Desutter-Grandcolas, 2006; Nattier et al., 2011; Vicente et al., 2017) of these genera are relatively plentiful. But more undescribed species can still be expected as exploration into understudied regions in Southeast Asia that include the species-rich island of Borneo (Tan et al., 2017). Even in areas such as Brunei Darussalam surrounded by the relatively well sampled Mount Kinabalu and Gunung Mulu National Park, many new species are still being discovered when intensive surveys are conducted (e.g., Tan \& Wahab, 2018). Compared to other parts of Sabah, the diversity of orthopterans in Sandakan is poorly known. Neglecting the northeastern part of Borneo will impede the comprehensive studies on the taxonomy and biodiversity of orthopterans in Borneo and in general Southeast Asia. Therefore, orthopteran surveys in Sandakan were conducted to collect new orthopteran material in order to facilitate future taxonomic revisions and species discovery.

Two species of Lebinthini were collected during the surveys. These include a new species of Lebinthus - Lebinthus sandakan sp. nov.-and a relatively widespread Cardiodactylus borneoe Robillard \& Gorochov, 2014. C. borneoe can be found in Borneo as well as Malay Peninsula but the male calling song of this species is still unknown (Robillard et al., 2014). Owing that there are individual variations in the male genitalia and close resemblance to other congeners (i.e., Cardiodactylus admirabilis Tan \& Robillard, 2014 and Cardiodactylus thailandia Robillard, 2011), bioacoustics analysis can help us better understand the species boundaries of these Cardiodactylus.

\section{Materials and Methods}




\title{
Materials
}

Field collections and observations were made in Rainforest Discovery Centre, Ulu Dusun Agriculture Research Station (Fig. 1A), and Kebun Cina (Sandakan Rainforest Park) (Fig. 1B) between 8 and 12 January 2019. Specimens were collected by sight only, by night and day. Whenever possible, in-situ images were taken using a Canon EOS 500D digital SLR camera with a compact-macro lens EF 100 $\mathrm{mm} \mathrm{f} / 2.8$ Macro USM and Canon Macro Twin Lite MT-24EX was used for lighting and flash. The specimens were preserved in absolute analytical-grade ethanol and later pinned and dry-preserved. A single hind leg from each specimen was also preserved in absolute analytic-grade ethanol for future molecular work. Newly collected specimens are deposited in the collections of the Forest Research Centre, Sandakan (FRC), Muséum national d'Histoire naturelle, Paris (MNHN), and the Zoological Reference Collection, Lee Kong Chian Natural History Museum, Singapore (ZRC). Part of the material was studied on loan from Zoological Institute, Russian Academy of Sciences, S. Petersburg, Russia (ZIN) and Bernice P. Bishop Museum, Department of Zoology, Honolulu, Hawaii, USA (BPBM).

\section{Examination of materials}

Male tegminal veins and cells follow terminology by Desutter-Grandcolas (2003) and Robillard \& Desutter-Grandcolas (2004). Male and female genitalia have been dissected in softened specimens by cutting the membranes between the paraprocts and the subgenital plate, or between the ovipositor and the subgenital plate respectively; they have been observed after cleaning with cold $\mathrm{KOH}$, and then kept in glycerine. Male genitalia are named according to Desutter (1987), modified in DesutterGrandcolas (2003) and Robillard \& Desutter-Grandcolas (2004). Abbreviations: see below.

Habitus images were made with a Canon EOS 500D digital SLR camera with a compact-macro lens EF $100 \mathrm{~mm}$ f/2.8 Macro USM. Close-up images of morphological features (including male genitalia) were done using a Canon EOS 500D digital SLR camera with a macro photo lens MP-E $65 \mathrm{~mm} \mathrm{f} / 2.8$ USM (1-5×). Canon Macro Twin Lite MT-24EX and Canon Macro Ring Lite MR-14EX were used for lighting and flash.

\section{Acoustic data}

Calling songs of males in the cages were recorded using a portable ultrasound recorder Echo Meter Touch (Wildlife Acoustics, Inc.) (sampling rate $=256 \mathrm{kHz}$ ) attached to an iPhone. Triggered recording was used with the Trigger Minimum Frequency set at $10 \mathrm{kHz}$. As temperature can influence frequency of calls, a temperature-humidity meter (Smartsensor AR867) was used to record the ambient temperature $\left({ }^{\circ} \mathrm{C}\right)$ and relative humidity $(\%)$ at the time of recording.

Acoustic analyses were performed using the computer software Avisoft-SASLab Pro version 4.40 (Specht, 2008). Song features were measured using the automatic commands under Avisoft-SASLab Pro.

\author{
Abbreviations \\ General morphology: \\ I, II, III: front, median, hind respectively (femora, legs, tibiae); \\ F: femora; \\ FW: forewing; \\ Tarsomere III-1: basal segment of hind leg tarsomere; \\ T: tibiae.
}

Male genitalia:

ec arc: ectophallic arc;

ec ap: ectophallic apodeme;

ec f: ectophallic fold

en ap: endophallic apodeme;

en s: endophallic sclerite;

ps 1: pseudepiphallic lophi; 
ps p: pseudepiphallic paramere;

r: rami.

Tegminal venation:

1A-4A: first to fourth anal veins;

$\mathrm{CuA}$ : anterior cubitus; $\mathrm{CuA} 1, \mathrm{CuA} 2, \ldots$. first, second, ... bifurcations of $\mathrm{CuA}$;

CuP: posterior cubitus;

MA, MP: anterior, posterior media veins;

$\mathrm{R}$ : radial vein;

c1-3: first to third cells of $\mathrm{C}$ alignment;

d1 cell (mirror): first cell(s) of D alignment;

$\mathrm{d} 2$ : second cell of $\mathrm{D}$ alignment;

e1: first cell of E alignment;

ha: harp area.

Measurements:

FIIIL: length of hind femora;

FIIIW: width of hind femora;

FWL: forewing length;

FWW: forewing width (at the level of maximal width);

Ias: inner spines on TIII dorsal side, above the spurs;

Ibs: inner spines on TIII dorsal side, between the spurs;

Oas: outer spines on TIII dorsal side, above the spurs;

Obs: outer spines on TIII dorsal side, between the spurs;

OL: ovipositor length;

PronL: pronotum length;

PronW: pronotum width;

ST: number of stridulatory teeth;

Tt: teeth on transverse section of the file;

Lt: teeth on longitudinal section of the file;

TIIIL: length of hind tibiae;

TaIIIs: spines on outer edge of third hind tarsomere, not including the apical spine.

\section{Systematic part}

Family Gryllidae

Subfamily Eneopterinae Saussure, 1874

Tribe Lebinthini Robillard, 2004

Genus Lebinthus Stål, 1877

Type species. Lebinthus bitaeniatus Stål, 1877

\section{Lebinthus sandakan, n. sp.}

(Figs. 2-10)

Type material. Holotype (male, SDK.19.37): Malaysia, Sabah, Sandakan, Rainforest Discovery Centre, N5.87534, E117.94093, 38.1 \pm 6.2 m.a.s.l., 9 January 2019, 2058 hours, on foliage near ground, coll. M. K. Tan, R. Japir, Momin Binti \& J. Y. Lee (FRC).

Allotype (female, SDK.19.38): collected together with the holotype (FRC).

Paratypes (12 males, 9 females), Malaysia, Sabah, Sandakan, all coll. M. K. Tan, R. Japir, Momin Binti, J. Y. Lee: 1 female (SDK.19.18, disintegrated specimen preserved in ethanol), Rainforest 
Discovery Centre, N5.87439, E117.94167, 42.8 \pm 5.0 m.a.s.l., 9 January 2019, 1041 hours, on leaf litter; 1 female (SDK.19.31), Rainforest Discovery Centre, N5.87549, E117.94146, 39.7 \pm 5.9 m.a.s.1., 9 January 2019, 2020 hours, on foliage near ground; 1 female (SDK.19.41), Ulu Dusun Agriculture Research Centre, N5.78397, E117.75998, 34.2 \pm 5.9 m.a.s.1., 10 January 2019, 0948 hours, leaf litter; 1 male (SDK.19.47), Ulu Dusun Agriculture Research Centre, N5.78397E, E117.76011, 47.4 \pm 6.1 m.a.s.l., 10 January 2019, 1050 hours, on root of trees; 1 male (SDK.19.49), Ulu Dusun Agriculture

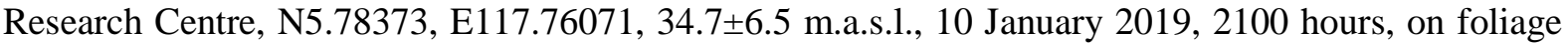
near ground (all ZRC). British N. Borneo, Sandakan Residency Gomantong Caves, 20 mi. S. Sandakan, 3 males, 22-25.xi.1958, T.C. Maa collector (BPBM). Malaysia, Borneo I., Sabah State, Sandakan Division, environs of Sukau vill. On Kinabatangan river (ca $35 \mathrm{~km}$ from sea), ca sea level, secondary-primary forest, 8-13.v.2013, A. Gorochov, M. Berezin, E. Tkatsheva: 6 males, 5 females (ZIN); 1 male (MNHN-EO-ENFIS1585); 1 female, molecular sample L91 (MNHN-EO-ENSIF1499).

Additional material examined. Malaysia, Borneo I., Sabah State, Sandakan Division, environs of Sukau vill. On Kinabatangan river (ca $35 \mathrm{~km}$ from sea), ca sea level, secondary-primary forest, 813.v.2013, A. Gorochov, M. Berezin, E. Tkatsheva: 2 juveniles (ZIN).

Diagnosis. Species of small size, very close to L. puyos Robillard, 2013 and L. polillensis Baroga, Yap \& Robillard, 2016, from the Philippines; it differs by dark brown patterns on pale face and by male genitalia with more elongated pseudepiphallus, short and rounded pseudepiphallic lophi and shape of pseudepiphallic parameres with a L-shaped strong apical sclerotization.

Description. Size small. Colouration brown with contrasted light and dark patterns, with slight individual variations (Figs. 2, 7, 8). Head dorsum (Figs. 3A, 3B) with four wide but faint brown longitudinal bands, medial bands each containing a thin black line; area posterior to eyes yellow. Eyes dark brown, with a paler dorsal longitudinal band. Fastigium wider than long, setose (with orange setae), dark brown (Figs. 3A, 3B). Scape whitish with faint darker patterns; antennae brown (Figs. 3C, 3D). Face (Figs. 3C, 3D) pale with variable dark patterns including longitudinal dark lines beneath scape, a dark triangle just above clypeus; front with four dark brown spots. Mouthparts variably mottled with dark brown and yellow brown (Figs. 3C, 3D); maxillary palpi generally yellow brown, apical segment with apex slightly expanding and darkened, subapical segment shorter than apical and third segments, third segments with more dark patterns (Figs. 3E, 3F). Lateral part of head (Figs. 3E, 3F) yellow, posterior to eyes and genae each with a black stripe. Pronotum: Dorsal disk (Figs. 3A, 3B) slightly trapezoidal (more prominent in males), anterior margin straight, posterior margin substraight; yellow brown mottled with dark brown, lateral edges always whitish, posterior area mostly dark brown. Lateral lobes (Figs. 3E, 3F) black, with ventral half mottled with pale yellow, ventral margin black (Figs. 3E, 3F). Legs (Fig. 2): Fore and mid legs light brown, femora with dark brown spots, tibiae with dark rings. Hind femora brown, with strong striated dark patterns on outer faces, knees dark brown; hind tibiae with dark rings. Tarsomeres I/III-1 yellow brown, apices dark brown. Abdomen red brown mottled with dark brown dorsally, yellowish brown ventrally. Cerci yellowish brown, with dark rings.

Male: FWs reaching $5^{\text {th }}$ abdominal tergite (Fig. 3A). FW colouration (Fig. 3A): Cells dark brown, not translucent; veins dark brown except anterior parts of anal veins orange brown; MA and MP orange brown, $\mathrm{M} / \mathrm{R}$ area whitish, without transverse veins; $\mathrm{R}$ dark brown, area between MA and $\mathrm{R}$ dark brown, rest of lateral field progressively lighter toward ventral margin, with dark brown longitudinal veins. FW venation (Fig. 3A): 1A widely curved (angle $>100^{\circ}$ ); stridulatory file about 1.8 $\mathrm{mm}$ long, slightly curved, with about 279 teeth $(\mathrm{n}=1)$ (Fig. 4), located on transverse part of 1A only. $\mathrm{CuP}$ not visible. Diagonal vein very faint. Harp wide, occupying most of dorsal field surface, with a strong transverse harp vein, poly-furcated anteriorly and delimiting a strong well-rounded false mirror, i.e. a distinctive area located on harp posterior corner (not homologous to the mirror of other cricket species: cell d1, Robillard \& Desutter-Grandcolas 2004a); posterior angle of harp raised. CuA curved innerly near apex, its distal part weak, surrounding the median fold, small, triangular, and located dorsally. Longitudinal veins of dorsal field strong apically, transverse veins very weak. Mirror (d1) not differentiated. Apical field absent, with no bifurcation of $\mathrm{CuA}$ posterior to diagonal vein. Lateral field with 6 strong longitudinal veins including M, R, Sc and four more ventral veins; latero-dorsal angle made by R; Sc without bifurcating veins. Supra-anal plate tongue-shaped (Fig. 3G).

Male genitalia (Fig. 5): Pseudepiphallic sclerite elongated and trapezoidal, not convex dorsally; posterior apex with triangular lophi, not setose, slightly wider than long and separated by a narrow V- 
shaped indentation; anterior margin slightly indented. Rami relatively long, nearly as long as rest of pseudepiphallic sclerite. Pseudepiphallic parameres irregularly shaped, apical end with a L-shaped strong sclerotization. Ectophallic arc curved to nearly straight. Ectophallic fold forming two elongated, thin and parallel sclerites. Ectophallic apodemes long and slightly divergent, exceeding anterior margin of pseudepiphallus. Endophallic sclerite wide and long, its posterior apex with a median triangular expansion and long lateral arms; endophallic apodeme made of wide lateral lamellas but without a median crest, also exceeding anterior margin of pseudepiphallus.

Female: FWs short (Fig. 3B), rounded, going slightly beyond middle of second tergite, not overlapping but close together; dorsal field light brown with four strong orange brown longitudinal veins, with transverse veins. Lateral field dark brown, with 4 strong dark brown longitudinal veins, dorsal most veins with transverse veins but less dense than in dorsal field. Subgenital plate trapezoidal, apical margin feebly concaved (Fig. 3H). Ovipositor shorter than hind femora; apex lanceolate, slightly denticulate on dorsal edge (Fig. 3I). Female papilla rounded basally, with a semi-circular sclerite prolonged by a short basal plate anteriorly; apex elongate and cylindrical, partly sclerotized, its ventral surface with thin transverse crests forming sharp rings dorsally (Fig. 6)

Juvenile. Head dorsum pale, otherwise dark brown mottled with pale yellow (Fig. 9).

Measurements. See Table 1.

Habitat and life history traits. L. sandakan lives in forest floor of different forested areas, ranging from old secondary/ primary forest (e.g., Rainforest Discovery Centre) to highly disturbed young secondary forest (or adinandra belukar) (e.g., Kebun Cina) (Figs. 1, 7-9). L. sandakan was found in Kebun Cina although no specimen was collected there. It is found on top of leaves and branches of low-lying plants or saplings and sometimes in the leaf litter.

Calling song (Fig. 10): At about $25{ }^{\circ} \mathrm{C}$, the calling song of $L$. sandakan consists of long trills (duration $=14.9 \pm 3.7 \mathrm{~s}$ ) made of more than 500 syllables, and starting by a group ca. 150-200 very short, indistinct irregular syllables with increasing intensity, followed by more regular syllables (syllable duration $=15.4 \pm 3 \mathrm{~ms}$; period $=26.9 \pm 3.5 \mathrm{~ms}$ ).

The spectrogram analysis (Fig. 10C) reveals that the frequency spectrum (Fig. 10D) presents different peak components along the syllable duration: initially, the syllables show a clear dominant peak at $18.8 \pm 0.28 \mathrm{kHz}$ corresponding to the second peak of a harmonic series with a first peak at ca. $9 \mathrm{kHz}$ being attenuated and an intermediate peak at ca. $27 \mathrm{kHz}$; in the rest of the syllable, the intermediary peak at $27 \mathrm{kHz}$ is not visible and the spectrum consists of a $19 \pm 0.1 \mathrm{kHz}$ fundamental frequency, with corresponding harmonics at ca. $37 \mathrm{kHz}$.

Etymology. This species is named after the type locality, Sandakan.

Genus Cardiodactylus Saussure, 1878

Type species: Cardiodactylus novaeguineae (Haan, 1842)

\section{Cardiodactylus borneoe Robillard \& Gorochov, 2014}

(Figs. 11, 12)

Robillard et al., 2014: 12; Dong et al., 2018: 6 (molecular phylogeny); Cigliano et al., 2019 (Orthoptera Species File).

Material examined: Malaysia, Sabah, Sandakan, Rainforest Discovery Centre, 1 female (SDK.19.6), N5.87410, E117.94366, 50.2 \pm 5.1 m.a.s.1., 8 January 2019, 2102 hours, on foliage, coll. M. K. Tan \& S. T. Toh (ZRC); 1 female (SDK.19.21, Fig. 11A) N5.87542, E117.94231, 31.1 \pm 4.8 m.a.s.1., 9 January 2019, 1930 hours, on foliage, coll. M. K. Tan, R. Japir, Momin Binti \& J. Y. Lee (FRC); 1 male (SDK.19.36, Figs. 9B-9D), N5.87547, E117.94110, 34.1 \pm 5.4 m.a.s.1., 9 January 2019, 2046 hours, under foliage calling, coll. M. K. Tan, R. Japir, Momin Binti \& J. Y. Lee (ZRC).

Calling song (Fig. 12): At $28.4^{\circ} \mathrm{C}$ and RH $74 \%$, the calling song of C. borneoe consists of doublets (or rarely triplets) of long syllables including strong amplitude modulation forming pulse-like structures. Echemes (doublet) last $660 \pm 75 \mathrm{~ms}$ with a period of $3.5 \pm 1.2 \mathrm{~s}$. Within doublets, syllables last $196 \pm 43 \mathrm{~ms}$, with a period of $372 \pm 47 \mathrm{~ms}$. Dominant frequency value is $17.6 \pm 0.4 \mathrm{kHz}$ with no clear harmonic structure. 
Habitat and life history traits. C. borneoe inhabits the dipterocarp forest in Sandakan and is typically found on or under the foliage of tree sapling or shrub at night.

Remark. The calling song of $C$. borneoe differs from that of Cardiodactylus admirabilis Tan \& Robillard, 2014 from Singapore by consisting of doublets with longer echeme duration (instead of triplets with shorter echeme duration of $205.6 \mathrm{~ms}$ ) and higher dominant frequency (instead of 14.3 $\mathrm{kHz}$ ). This is despite of the similarities in the morphology and genitalia of these two species. Another morphologically similar species is Cardiodactylus thailandia Robillard, 2011 from Thailand but its song is unknown.

\section{Acknowledgements}

The authors thank Momin Binti, John Lee Yukang, Saudi Bintang (all from Forest Research Centre) and Siew Tin Toh for field assistance; Andrej V. Gorochov for loans of specimens from ZIN and BPBM. Permission to collect and export material in Sandakan was approved by the Sabah Biodiversity Centre (JKM/MBS.1000-2/3 JLD.3 (99)). The work in Sandakan was granted by the Orthoptera Species File Grant 2019 under the taxonomic research project with the title "Contribution to the species diversity and acoustic data on Orthoptera from Sandakan (Borneo, East Malaysia, Sabah)". The work of MKT was also supported by the Lady Yuen Peng McNeice Graduate Fellowship of the National University of Singapore.

\section{References}

Cigliano, M.M., Braun, H., Eades, D.C. \& Otte, D. (2019) Orthoptera species file online. Version 5 (5.0). Available from: http://orthoptera.speciesfile.org/HomePage/Orthoptera/HomePage.aspx (accessed 8 March 2019).

Desutter, L. (1987) Structure et évolution du complexe phallique des Gryllidea (Orthoptera) et classification des genres néotropicaux de Grylloidea.1ère partie. Annales de la Société Entomologique de France (N.S.), 23, 213-239.

Desutter-Grandcolas, L. (2003) Phylogeny and the evolution of acoustic communication in extant Ensifera (Insecta, Orthoptera). Zoologica Scripta, 32, 525-561. https://doi.org/10.1046/j.14636409.2003.00142.x

Dong, J., Kergoat, G.J., Vicente, N., Rahmadi, C., Xu, S., \& Robillard, T. (2018) Biogeographic patterns and diversification dynamics of the genus Cardiodactylus Saussure (Orthoptera, Grylloidea, Eneopterinae) in Southeast Asia. Molecular Phylogenetics and Evolution, 129, 1-14. https://doi.org/10.1016/j.ympev.2018.06.001

Nattier, R., Robillard, T., Desutter-Grandcolas, L., Couloux, A. \& Grandcolas, P. (2011) Older than New Caledonia emergence? A molecular phylogenetic study of the eneopterine crickets (Orthoptera: Grylloidea). Journal of Biogeography, 38, 2195- 2209. https://doi.org/10.1111/j.1365-2699.2011.02563.x

Robillard, T. \& Desutter-Grandcolas, L. (2006) Phylogeny of the cricket subfamily Eneopterinae (Insecta, Orthoptera, Grylloidea, Eneopteridae) based on four molecular loci and morphology. Molecular Phylogenetics and Evolution, 40, 643-661. https://doi.org/10.1016/j.ympev.2005.10.019

Robillard, T. \& Tan, M.K. (2013) A taxonomic review of common but little known crickets from Singapore and the Philippines (Insecta: Orthoptera: Eneopterinae). Raffles Bulletin of Zoology, 61 (2), 705-725.

Robillard, T., Dong, J., Legendre, F. \& Agauvoa, S. (2016) The brachypterous Lebinthini crickets from Papua New Guinea, with description of two new genera and four new species (Orthoptera: Gryllidae: Eneopterinae). In: Robillard, T., Legendre, F., Villemant, C. \& Leponce, M. (Eds.), Insects of Mount Wilhelm, Papua New Guinea, 109. Mémoires du Muséum national d'Histoire naturelle Paris, pp. 149-202.

Robillard, T., Gorochov, A.V., Poulain, S., \& Suhardjono, Y.R. (2014) Revision of the cricket genus Cardiodactylus (Orthoptera, Eneopterinae, Lebinthini): the species from both sides of the 
Wallace line, with description of 25 new species. Zootaxa, 3854, 1-104.

https://doi.org/10.11646/zootaxa.3854.1.1

Specht, R. (2009) Avisoft-SASLab Pro - Sound Analysis and Synthesis Laboratory. Avisoft Bioacoustics, Berlin.

Tan, M.K., Choi, J. \& Shankar, N. (2017a) Trends in new species discovery of Orthoptera (Insecta) from Southeast Asia. Zootaxa, 4238 (1), 127-134. https://doi.org/10.11646/zootaxa.4238.1.10

Tan, M.K. \& Robillard, T. (2014) A new species of Cardiodactylus (Orthoptera: Grylloidea:

Eneopterinae) from Singapore. Zootaxa, 3764 (3), 364-376. http://dx.doi.org/10.11646/zootaxa.3764.3.6

Tan, M.K. \& Wahab, R.A. (2018) Preliminary study on the diversity of Orthoptera from Kuala

Belalong Field Studies Centre, Brunei Darussalam, Borneo. Journal of Orthoptera Research, 27 (2), 119-142. https://doi.org/10.3897/jor.27.24152

Vicente, N.M., Olivero, P., Lafond, A., Dong, J. \& Robillard, T. (2015) Gnominthus gen. nov., a new genus of crickets endemic to Papua New Guinea with novel acoustic and behavioural diversity (Insecta, Orthoptera, Gryllidae, Eneopterinae). Zoologischer Anzeiger - A Journal of Comparative Zoology, 258, 82-91. https://doi.org/10.1016/j.jcz.2015.06.005

Vicente, N., Kergoat, G.J., Dong, J., Yotoko, K., Legendre, F., Nattier, R. \& Robillard, T. (2017) In and out of the Neotropics: historical biogeography of Eneopterinae crickets. Journal of Biogeography, 44, 2199-2210. https://doi.org/10.1111/jbi.13026

TABLE 1. Measurements (all in $\mathrm{mm}$ ) and counts of Lebinthus sandakan sp. nov. (mean in brackets).

\begin{tabular}{|l|c|c|c|c|c|c|c|c|}
\hline & PronL & PronW & FWL & FWW & FIIL & FIIIW & TIIIL & OL \\
\hline Holotype & 2.4 & 3.7 & 3.8 & 3.7 & 9.7 & 3.2 & 8.6 & - \\
\hline $\begin{array}{l}\text { Males } \\
(\mathrm{n}=3)\end{array}$ & $\begin{array}{c}2.3-2.5 \\
(2.4)\end{array}$ & $\begin{array}{c}3.3-3.7 \\
(3.5)\end{array}$ & $\begin{array}{c}3.8-4.0 \\
(3.9)\end{array}$ & $\begin{array}{c}3.2-3.7 \\
(3.4)\end{array}$ & $\begin{array}{c}9.6-9.7 \\
(9.7)\end{array}$ & 3.2 & $\begin{array}{c}8.3-8.6 \\
(8.5)\end{array}$ & - \\
\hline Allotype & 2.4 & 4.0 & 1.9 & 2.2 & 9.8 & 3.2 & 8.2 & 6.9 \\
\hline $\begin{array}{l}\text { Females } \\
(\mathrm{n}=3)\end{array}$ & $\begin{array}{c}2.2-2.4 \\
(2.3)\end{array}$ & $\begin{array}{c}3.2-4.0 \\
(3.5)\end{array}$ & $\begin{array}{c}1.7-1.9 \\
(1.8)\end{array}$ & $\begin{array}{c}2.2-2.3 \\
(2.2)\end{array}$ & $\begin{array}{c}9.4-10.4 \\
(9.9)\end{array}$ & $\begin{array}{c}3.2-3.5 \\
(3.3)\end{array}$ & $\begin{array}{c}8.2-9.1 \\
(8.5)\end{array}$ & $\begin{array}{c}6.8-7.3 \\
(7.0)\end{array}$ \\
\hline & Ias & Ibs & Oas & Obs & TaIIIs & & & \\
\hline Holotype & 7 & 3 & 9 & 5 & 2 & & & \\
\hline $\begin{array}{l}\text { Males } \\
(\mathrm{n}=3)\end{array}$ & $6-7(7)$ & $2-3(3)$ & $9-10(9)$ & $4-5(5)$ & $2-3(3)$ & & & \\
\hline Allotype & 5 & 1 & 9 & 3 & 2 & & & \\
\hline $\begin{array}{l}\text { Females } \\
(\mathrm{n}=3)\end{array}$ & $5-7(6)$ & $1-3(2)$ & $9-10$ & $3-5(4)$ & $2-3(2)$ & & & \\
\hline
\end{tabular}

\section{Figure captions}



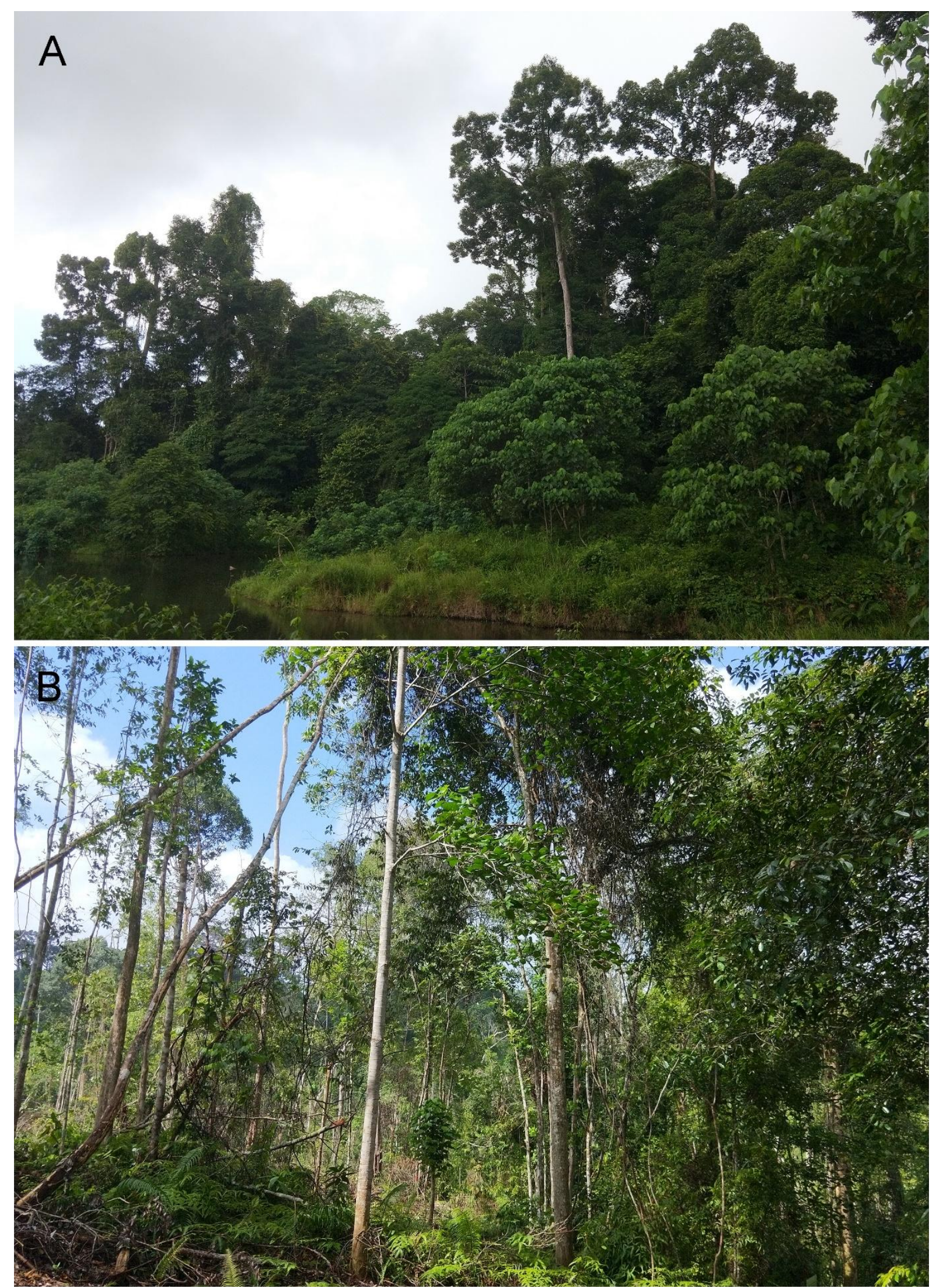

FIGURE 1. Forests that Lebinthus sandakan sp. nov. lives in: Ulu Dusun Agriculture Research Station (A), and Kebun Cina-forest was affected by windfall in August 2018 (B). 


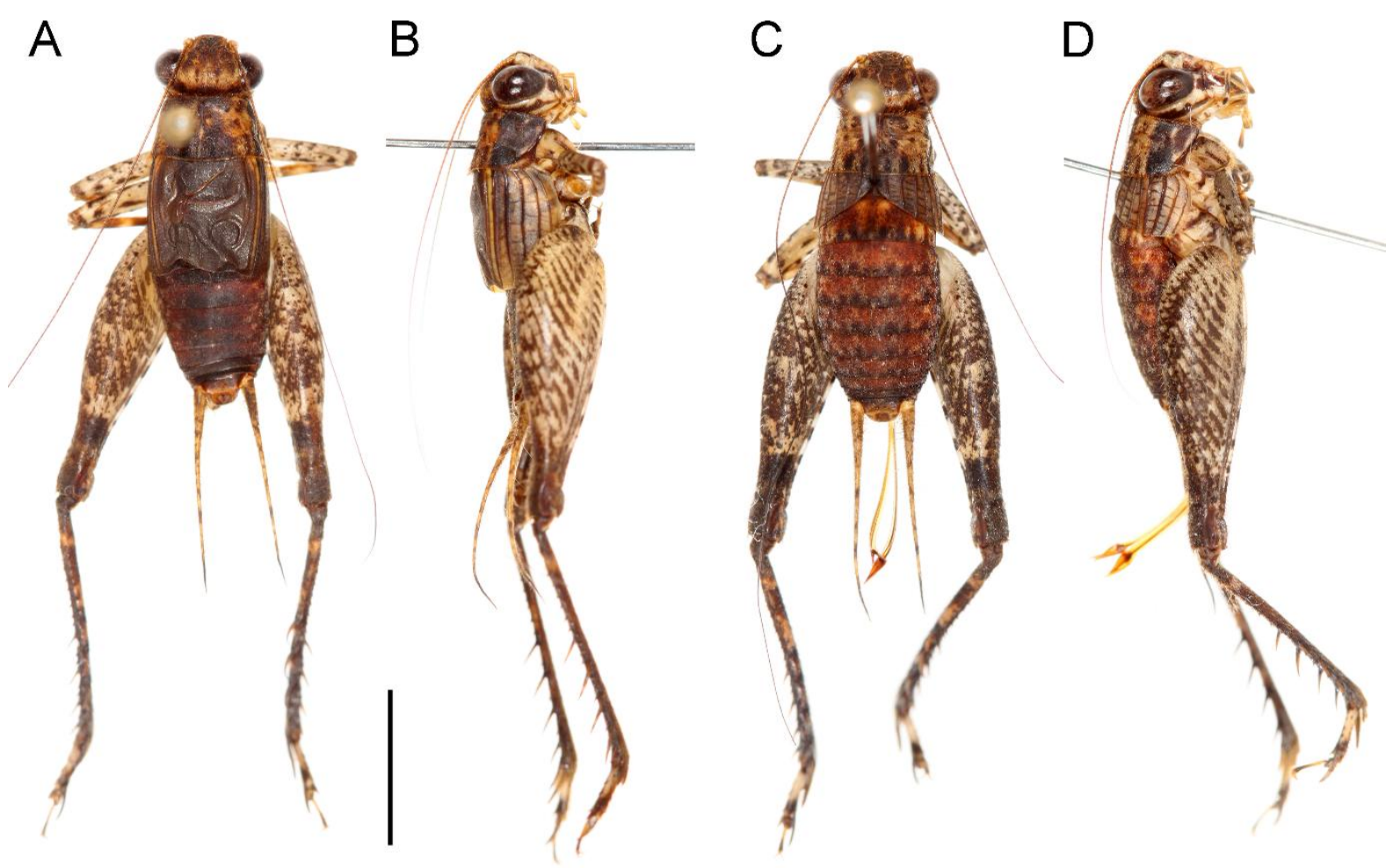

FIGURE 2. Habitus of Lebinthus sandakan sp. nov.: male paratype (A, B) and female allotype (C, D) in dorsal (A, C) and lateral (B, D) views. Scale bar: $5 \mathrm{~mm}$. 

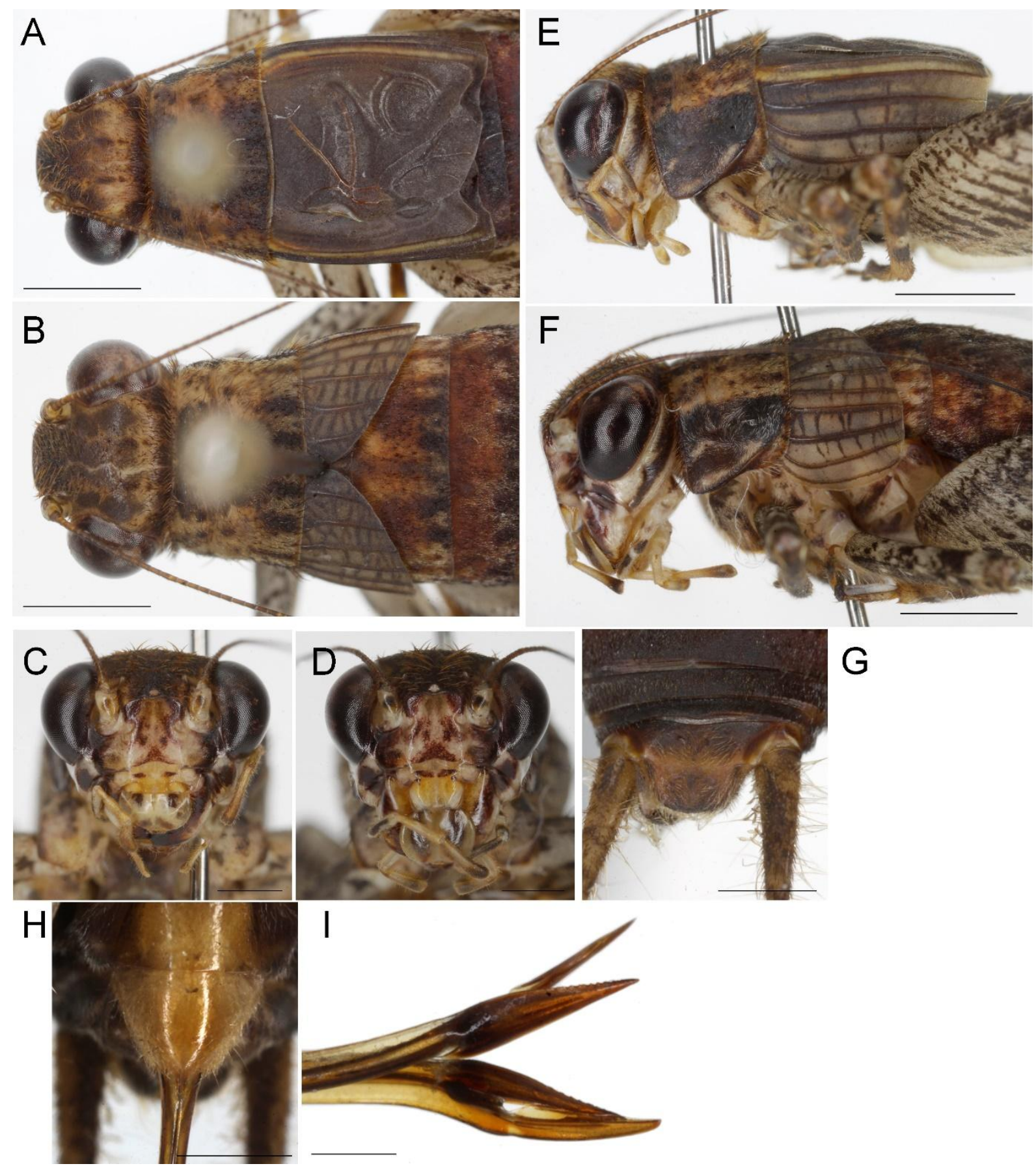

G

FIGURE 3. Lebinthus sandakan sp. nov.: male (A, C, E) and female (B, D, F) dorsum of head and pronotum (A, B), face in anterior view $(\mathrm{C}, \mathrm{D})$, head and pronotum in lateral view $(\mathrm{E}, \mathrm{F})$, male abdominal apex in dorsal view $(\mathrm{G})$, female subgenital plate in ventral view $(\mathrm{H})$, apex of ovipositor $(\mathrm{I})$. Scale bars: $2 \mathrm{~mm}$ (A, B, E, F), $1 \mathrm{~mm}(\mathrm{C}, \mathrm{D}, \mathrm{G}, \mathrm{H}), 0.5 \mathrm{~mm}(\mathrm{I})$. 


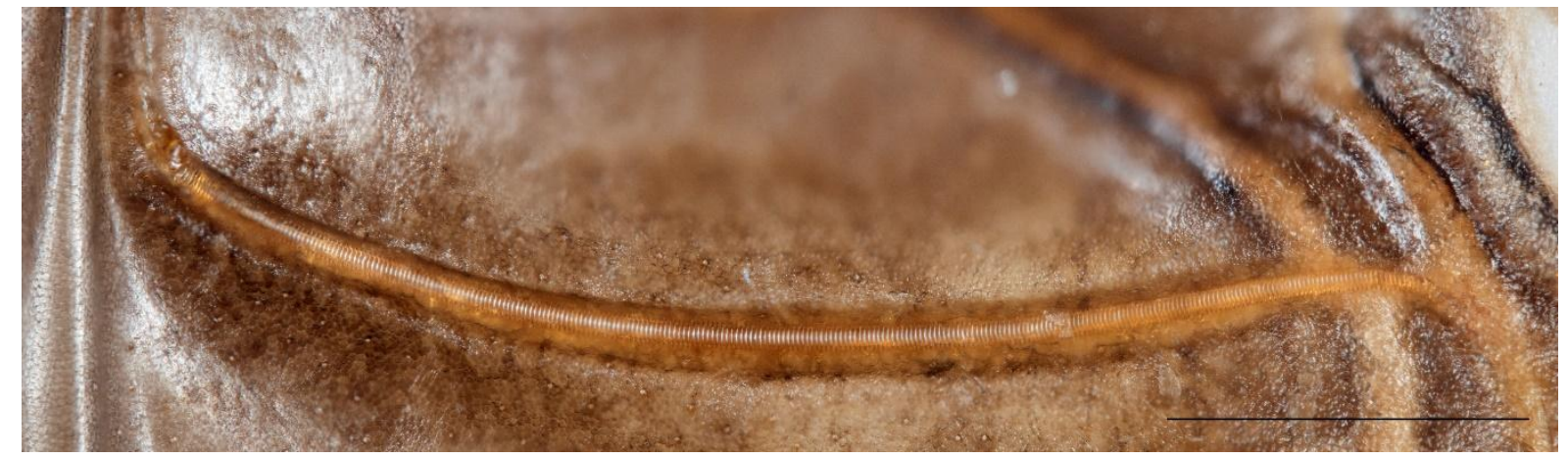

FIGURE 4. Lebinthus sandakan sp. nov.: male stridulatory file on left tegmen. Scale bar: $0.5 \mathrm{~mm}$ 


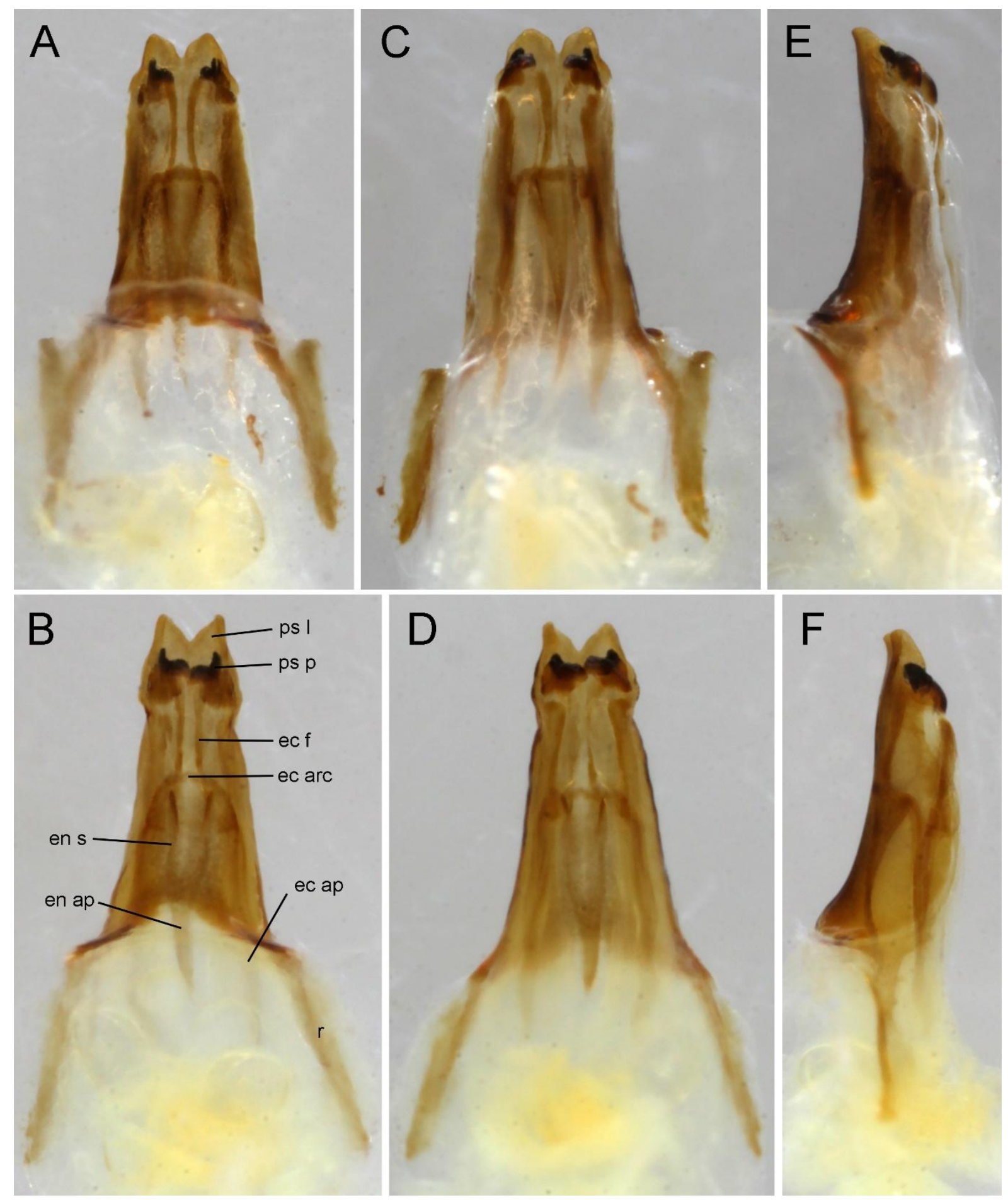

FIGURE 5. Male genitalia of Lebinthus sandakan sp. nov.: male holotype (A, C, E) and paratype (B, $\mathrm{D}, \mathrm{F})$ in dorsal $(\mathrm{A}, \mathrm{B})$, ventral $(\mathrm{C}, \mathrm{D})$ and lateral $(\mathrm{E}, \mathrm{F})$ views. 

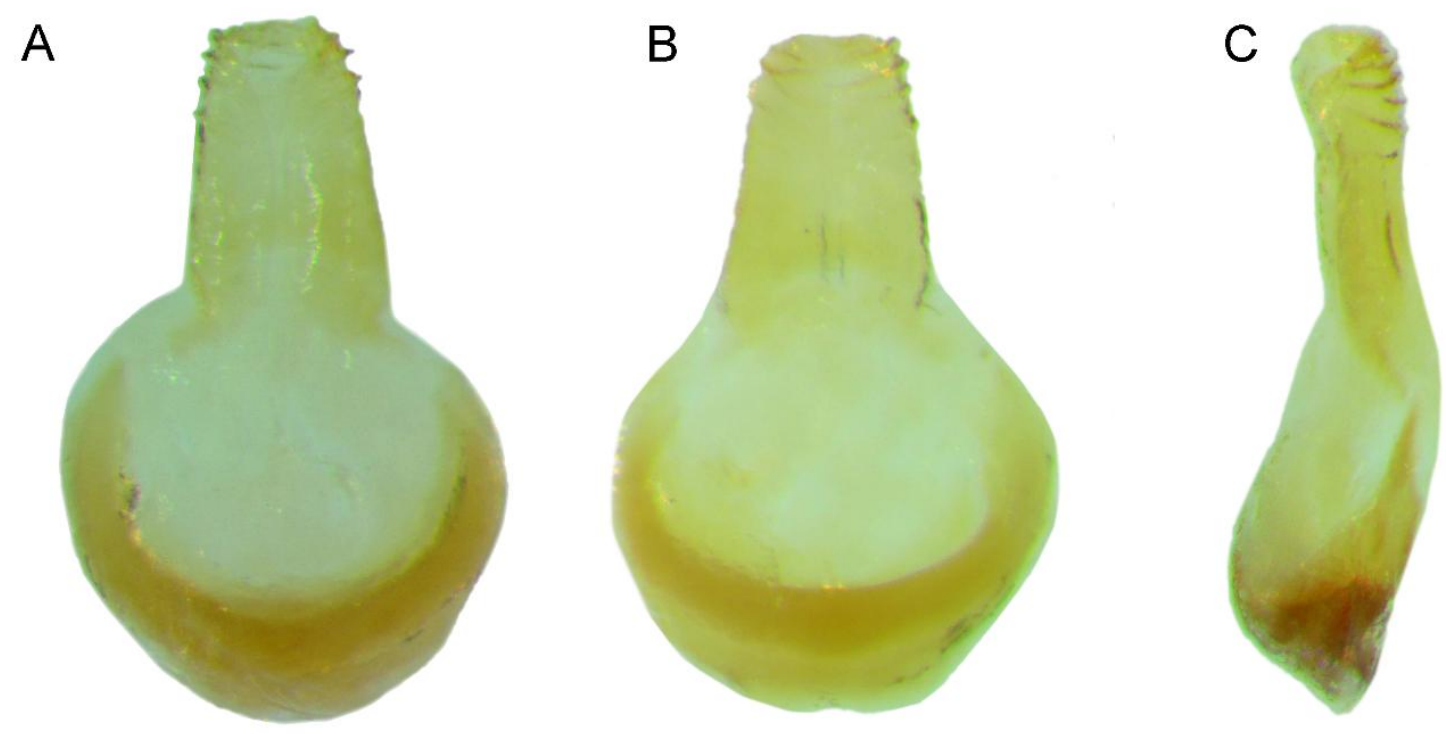

FIGURE 6. Female papilla of Lebinthus sandakan sp. nov. in dorsal (A), ventral (B) and lateral (C) views. Scale bar: $0.5 \mathrm{~mm}$. 

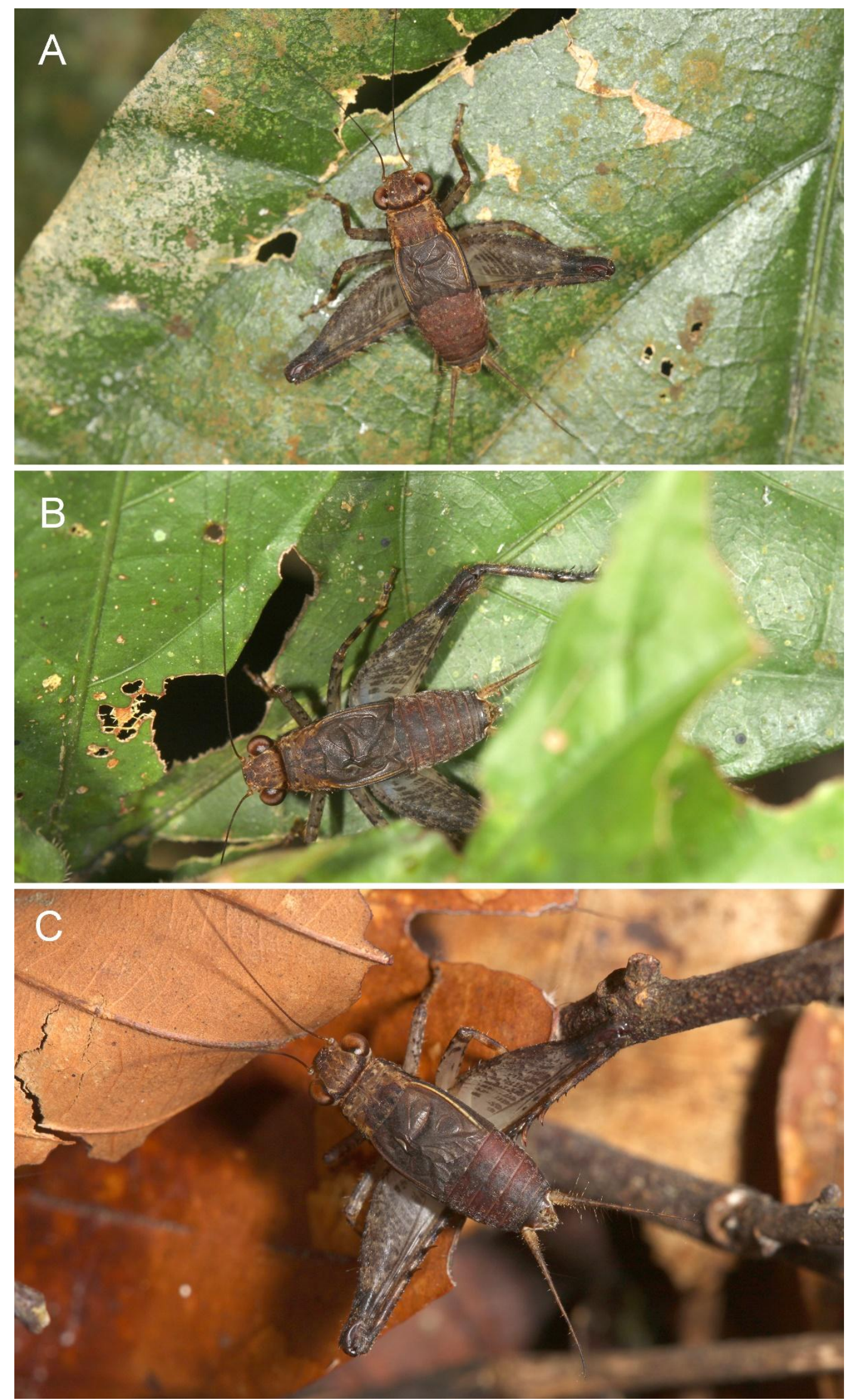

FIGURE 7. Lebinthus sandakan sp. nov. males in their natural microhabitats when alive. Holotype is (B). 

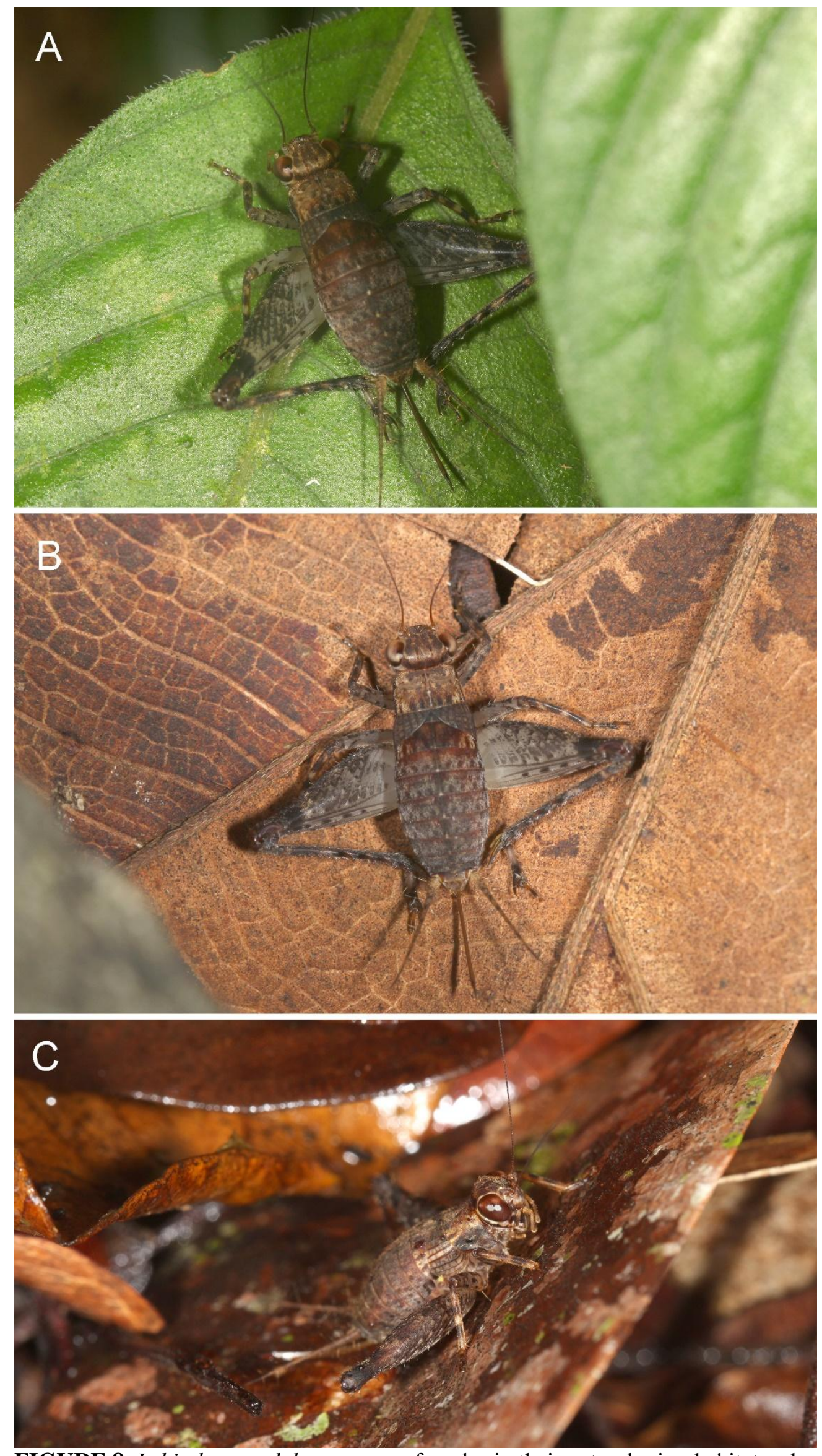

FIGURE 8. Lebinthus sandakan sp. nov. females in their natural microhabitats when alive. 

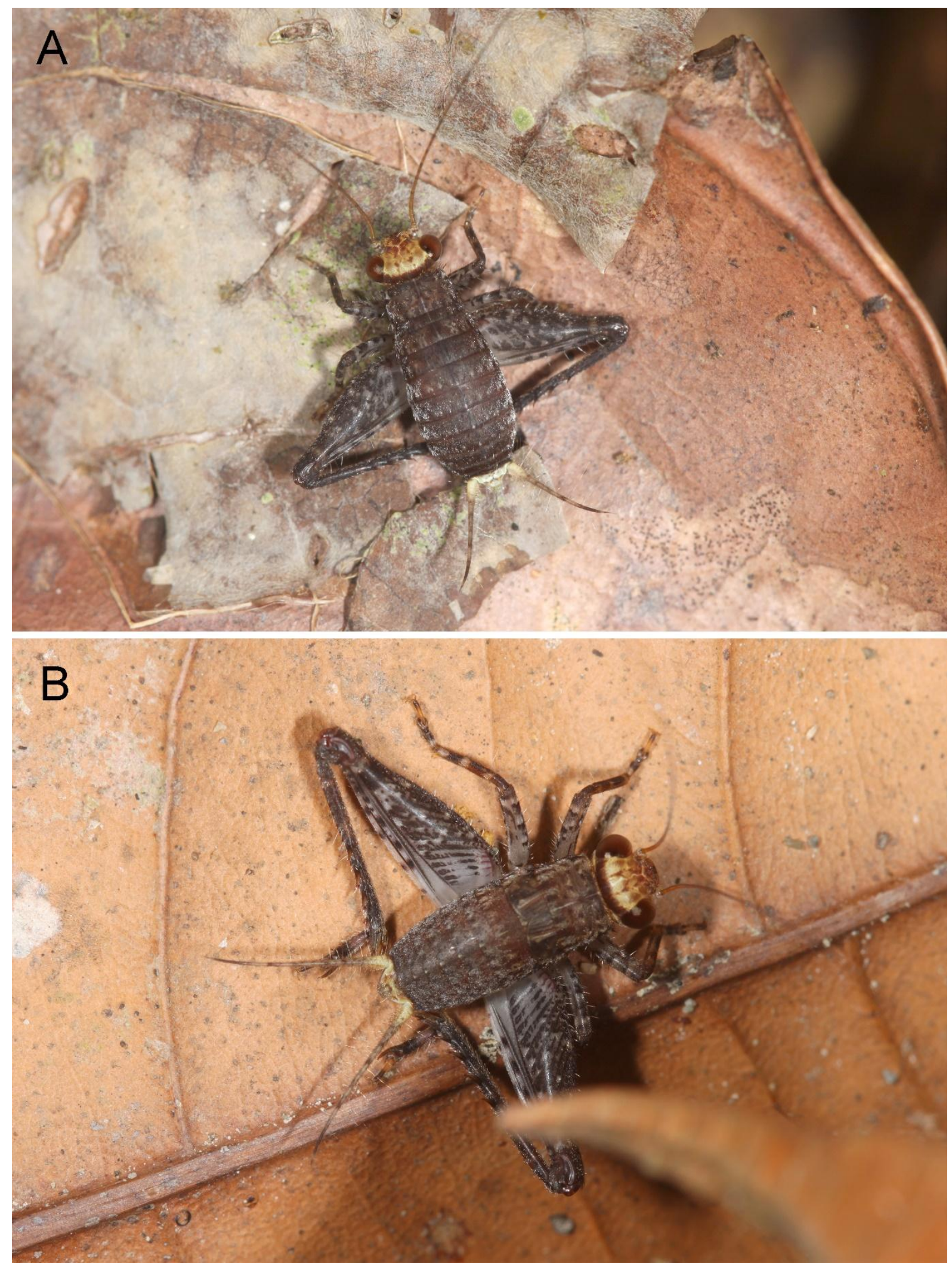

FIGURE 9. Lebinthus sandakan sp. nov. juveniles in their natural microhabitats when alive. 

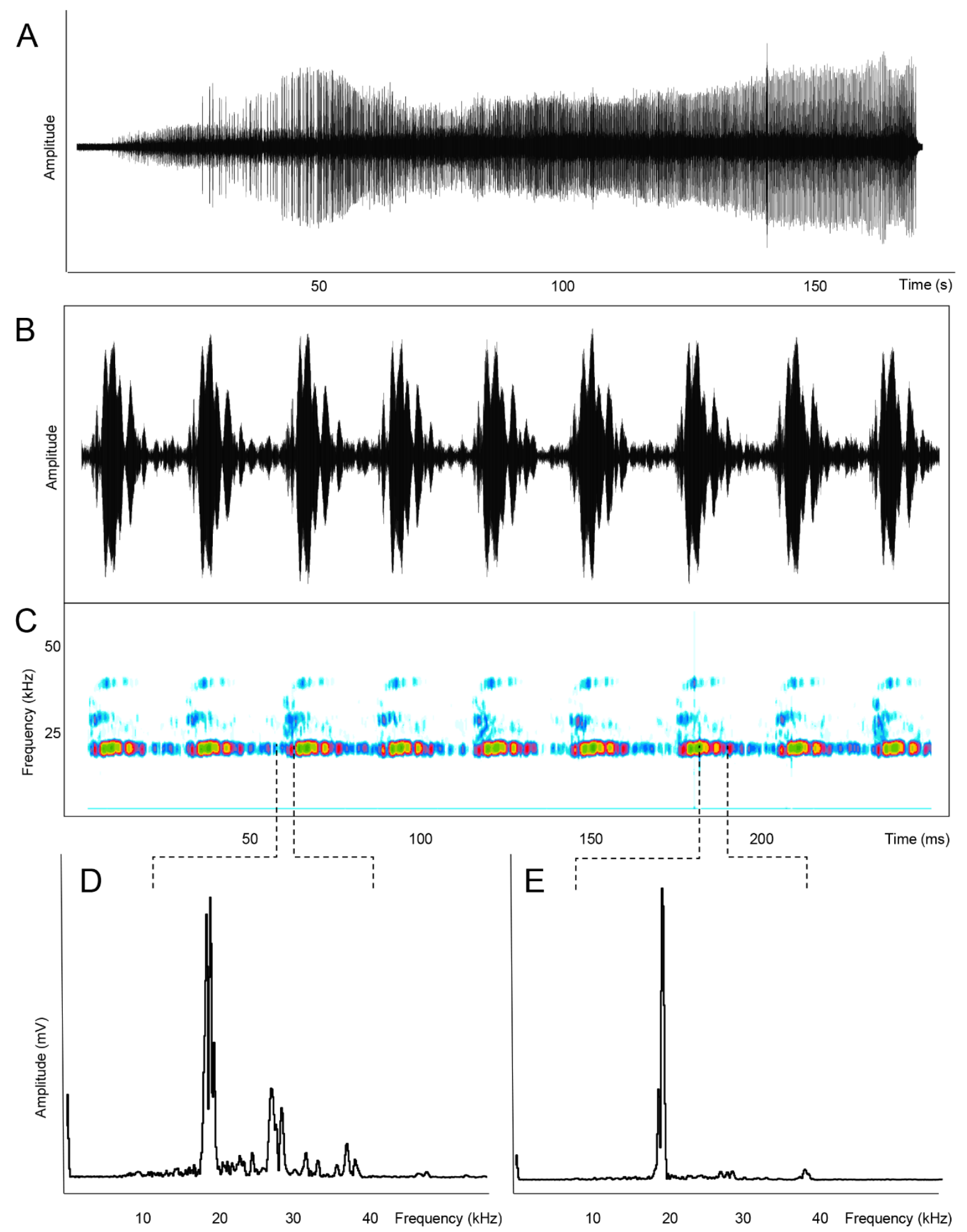

FIGURE 10. Calling song of Lebinthus sandakan sp. nov. of paratype: oscillogram of 1 echeme (A), detailed oscillogram of trill part of echeme (B) and corresponding spectrogram (C); power spectrums of beginning of syllble (D), of ending part of syllable (E). 

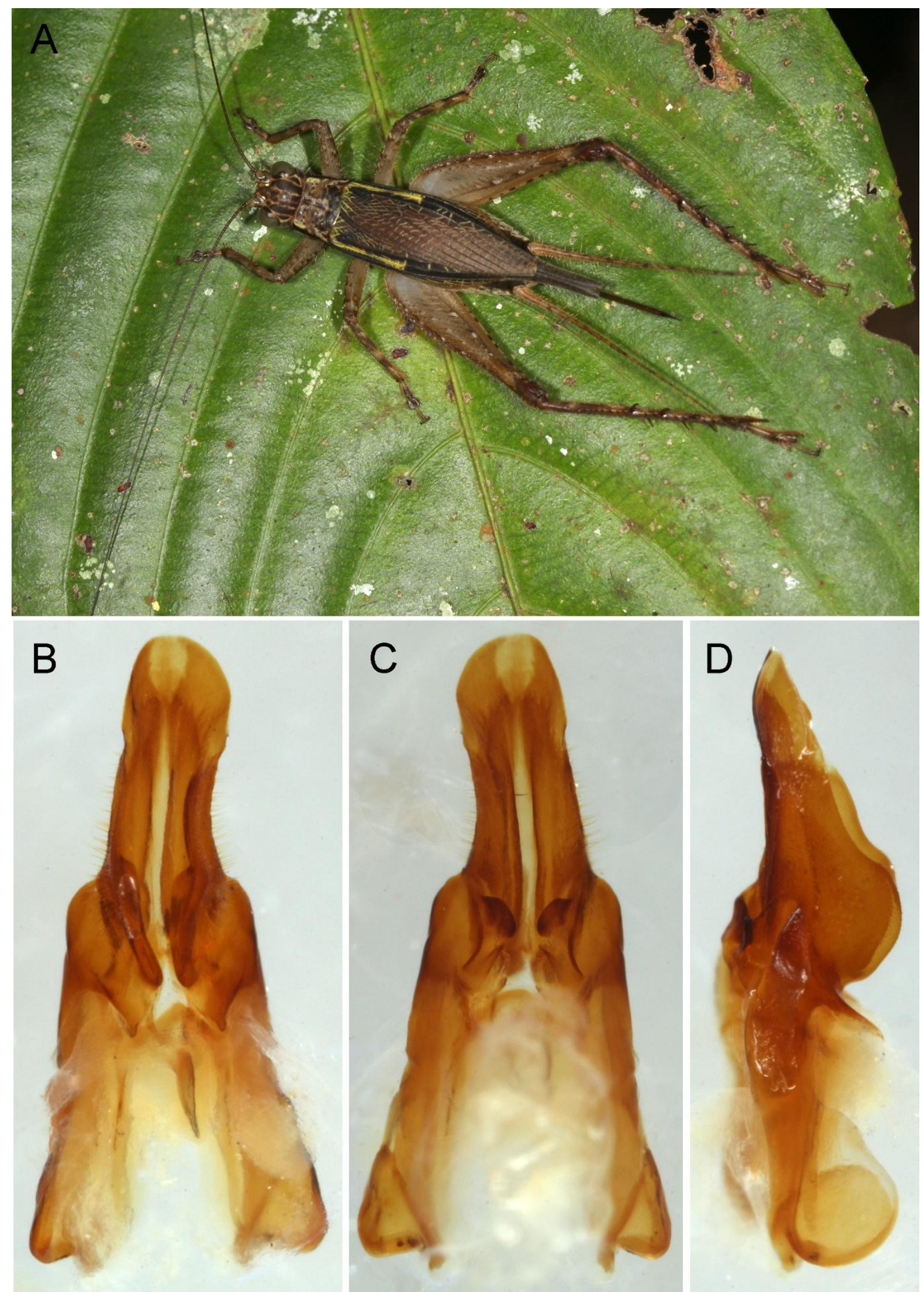

FIGURE 11. Cardiodactylus borneoe Robillard \& Gorochov, 2014 from Sandakan: female in its natural microhabitat when alive (A); male genitalia in dorsal (B), ventral (C) and lateral (D) views. 

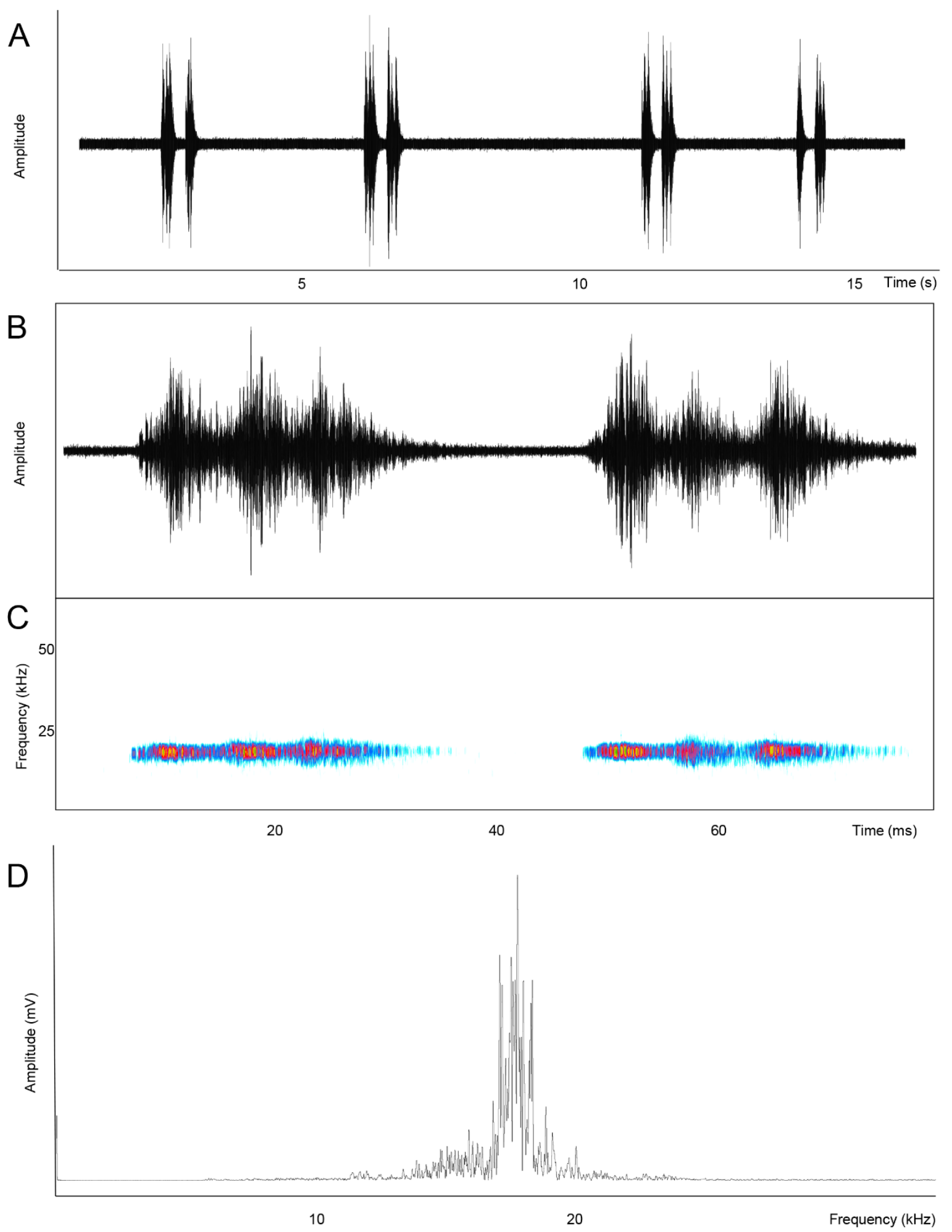

FIGURE 12. Calling song of Cardiodactylus borneoe Robillard \& Gorochov, 2014 from Sandakan: oscillogram of 3 echemes (A), detailed oscillogram of 1 echeme (B), spectrogram of 1 echeme (C), power spectrum (D). 